REPORTS OF MORPHOLOGY
Official Journal of the Scientific Society of Anatomists,
Histologists, Embryologists and Topographic Anatomists
of Ukraine
journal homepage: https://morphology-journal.com

\title{
Structural and functional transformation of the small intestine wall in the conditions of the functioning of the artificial urinary reservoir in the experiment
}

\section{Savchuk R.V., Kostyev F.I., Zhukovskij D.A., Nasibullin B.A. ${ }^{1}$}

Odessa National Medical University, Department of Urology and Nephrology, Odesa, Ukraine;

'State Institution "Ukrainian Scientific Research Institute of Medical Rehabilitation and Balneology of the Ministry of Health of Ukraine", Odesa, Ukraine

\section{ARTICLE INFO}

Received: 17 November, 2017

Accepted: 10 January, 2018

UDC: $616-092-616.6-616-006$

CORRESPONDING AUTHOR

e-mail: Savrus7@rambler.ru Savchuk R.V.
Morphological changes of the wall of the artificial urinary bladder are various and its investigation continues from the moment of the creation of the first conduit on the ileum's section. The aim of the work is to explore the structural-functional transformation of the mucous and the neobladder wall in 12 months after ileocystoplasty in the experimental conditions on mini-pigs. The results of the neobladder's experimental model, created by the execution of cystectomy and ileocystoplasty in 9 experimental mini-pigs are the material of this work. 12 months after the operation of modeling the urinary bladder, animals were removed from the experiment of nembutal overdosing, following the provisions of "The European convention for the Protection of vertebrate animals being in use for experiments or for other scientific purposes". Our morphological changes of the artificial urinary bladder, formed from the segment ileum 12 months after the orthotopic ileoplasty proved significant ultra-structural changes in the neobladder's epithelial layer. Ileum's villi within the conditions of the artificial urinary bladder are decreased and smoothed, epithelial cells are similar to the interjacent epithelium. The connective-tissue plate is thickened and becomes callous, the muscular layer is also thickened. The samples of the ileum, that remained in the normal environment without the compatibility with urine, did not undergo the significant morphological transformations and did not differ from the samples of the intact ileum. Thetransplantation of the ileumsegment for performing new, not-programmed functions causes it to adapt to new conditions, although the urinary bladder and the ileum have different origins and structures from the very beginning. New aggressive conditions and constant contact with urine lead to the transformation of the mucous of the ileum and acquire new features necessary for performing new functions.

Keywords: radical cystectomy, ileocystoplasty, transformation of the mucous, neobladder.

\section{Introduction}

Bladder disease with loss of reservoir capacity and function, damage by the tumor process, as well as the complication of specific and non-specific inflammatory diseases requiring its complete removal or resection, led to rapid development of reconstructive surgery of bladder [4, $7,8,20]$. The main material for restoring the functional capabilities of the bladder (accumulative and evacuator) are different sections of the gastrointestinal tract $[3,5,15]$. Many studies have been conducted on the effectiveness and safety of the use of the stomach, the area of the large and small intestines, but the best transplant was recognized area of iliac intestine, due to the smallest electrolyte disturbances and possible adaptive abilities [9, 12, 19]. The study of morphological changes in the wall of the artificial bladder continues from the moment of the first conduit from the region of the ileum. Many researchers note the progressive atrophy of the villi and microvilli [10], and the number of glass-shaped cells decreases with time $[11,18]$.

The implementation of new, not programmed functions, the impact of the aggressive environment on the mucous artificial bladder, the possibility of its adaptation and transformation determined our interest in the study of structural 
changes in the neobladder dynamics in the dynamics.

Aim: to study the structural and functional transformation of the mucosa and the neobladder wall 12 months after ileocystoplasty on mini-pigs under experimental conditions.

\section{Materials and methods}

The material of this work were the results of an experimental model of neobladder, created by ileocystoplasty of 9 experimental mini-pigs.

The simulation was carried out by performing cystectomy followed by ileocystoplasty in female pigs. The choice of an experimental object is due to anatomical considerations - in the female urethra is straight and 5-7 times shorter than that of males [2].

The procedure for surgical intervention was follows. Under intravenous anesthesia, pigs aged 4-5 months and weighing 8-10 kg after processing of the surgical field in the position on the back three times performed a cut. The top of the bladder was seized by forceps and tucked up. All bleeding vessels were tucked on both sides. Separated the front wall of the bladder. Crossed the urethra, the bladder separated them from the rectum. The bladder was removed. Retreating $15 \mathrm{~cm}$ from the ileocecal valve, the end of the isolated intestinal segment was sutured with continuous serousmuscle sutures of vicryl 4-0. During theanti-mesenteric edge, a distal part of the idiopathic segment was dissected (up to $10 \mathrm{~cm}$ ). The cut part of the segment U-shapedly stacked adjacent edges of both knees were sewn together by a series of continuous serous-muscle sutures vicryl 4-0. The lower part of the resulting $\mathrm{U}$-shaped segment was transversely upward.

Before cross-linking the free edges of the dissected segment, the urethral catheter number $3 \mathrm{Fr}$ was installed in the tetanus elbow, the ends of which were removed through the wall of the reservoir. In the most caudal part of the reservoir was made an opening, to which the urethra was sutured with 6 sutures of vicryl 4-0. After conducting through the urethra of Foley's catheter number $8 \mathrm{Fr}$, the sutures were tied. The reservoir was drained by a cystostomy tube $12 \mathrm{Fr}$, which was withdrawn along with the ureter stents through the vessel wall. The reservoir stood in place and formed an isoperistaltic knee. The ileum was dissected at the level of intersected pre-ureters - $10 \mathrm{~cm}$ higher than the iliac-intestinal reservoir. The ureter is obliquely cut, cut along and anastomosed "end to side" with the proximal unbranched part of the iliac-intestinal segment. Stents that are located inside the segment, are carried out in the ureter. Restore the intestinal continuity. Stents are drawn through the anterior abdominal wall, through the counter-aperture in the small pelvis install drainage. Thewound is closed with vicryl stitches.

The area of the bladder wall was taken during cystectomy, at the same time, surgical intervention was removed from the area of the ileum wall. Data obtained in the study of these fragments of intact organs served as controls.

12 months after the bladder simulation, animals were drawn from the experiment by overdosing Nembutal, following the provisions of the "European Convention for the Protection of Vertebrate Animals Used for Experiments or for Other Scientific Purposes" (Strasbourg, 1986).

Removed the area of the wall of the neobladder and the area of the ileum wall. The volume of each fragment of tissue taken as control and in order to evaluate the result was $1 \mathrm{~cm} 3$. The collected material was fixed in a $4 \%$ solution of paraformaldehyde. Then the material was carried out through the spirits of increasing concentration and poured into celloidin according to the generally accepted method [2]. The use of celloidin is associated with the need for maximum sparing effect on the tissues under study. From the received blocks, histological sections of thickness 7-9 microns were made, which were stained with hematoxylin and eosin. The obtained glasses were studied under a light microscope. When studying preparations under a microscope, the peculiarities of the structure of the layers of the organs examined were evaluated.

\section{Results}

In the macroscopic study of the ileum in intact animals, the lamination of its wall was clearly visible. The surface of the mucous membrane is velvety, transverse folds are expressed.

Microscopically, the serous wall of the intestine is represented by a single-layer cubic epithelium. Epithelial cells contain medium-sized rounded nuclei, juicily stained with hematoxylin solution. Muscle membrane with a clear division into two layers. From the submucosal basis and the serous membrane, it is separated by thin fibrous plates. Layers of the muscular membrane differ in the direction of the myocyte beams (longitudinal and circular). The bundles of myocytes are separated by thin interstitial layers containing fibrous fibers and individual fibroblasts with extracted dark nuclei. Myocytes with a homogeneous cytoplasm and juicy oval nuclei.

Submucosal base is represented by fibrous fibers, which are assembled into beams and form a mesh structure; thinwalled, moderately blood-filled vessels of small caliber; a small amount of intermediate substance of moderate eosinophilic color, in which diffused lymphoid elements. Closer to the inner surface, small lymphoid follicles of the usual structure are determined. In addition, Peyer's patch are found, representing a cluster of 2-3 follicles of almost rectangular shape with a moderate density of lymphoid elements in a rounded, hermetic center and with a dense position in the peripheral zone.

In the mucous membrane, a submucosal plate can be isolated from the beams of fibrous fibers and muscle cells, among which there are numerous lymphoid elements. On the surface mucous membrane forms numerous villi. The body of the villi is characterized by a thin-walled vessel and numerous lymphoid elements. The top of the villi is covered by the prismatic epithelium, the epithelial cells contain oval dense nuclei, which are located as "palisade". Between them, the glass-shaped cells, which are rich in mucus, are 
determined. In the depth between the villi, crypts are formed (Fig. 1).

The macroscopic examination of the intact mini-pig bladder showed that the outer surface has grayish-pinkish color, shiny, smooth. By palpation wall is elastic, on the section noticeable layering, the inner surface is folded, pinkish-gray, moist.

Microscopy of the preparations of the wall of a healthy urinary bladder revealed that the external, serous membrane is formed by a single-layer cubic epithelium. The nuclei of epithelial cells are of medium size, oval, moderate in color. In some places epitheliocytes form small "influences" in which the nuclei are viewed in 2-3 rows. The thin plate of fibrous fibers and vessels of small caliber separates the serous membrane from the muscular membrane. The muscular layer is three-layered, layers separated by a layer of fibrous tissue containing vessels. The width of these layers is greater than in the intestine wall. Muscle beams are in interstitial wall, thin, containing single fibroblasts. Myocytes in tufts are densely packed, moderate in width, have juicy nuclei, and the cytoplasm is homogeneous. In bundles myocytes are unidirectional. Between the beams and in the boundary plates, numerous small vessels of moderate blood filling are observed.

The submucosal plate is represented by an intermediate substance and bundles of fibrous fibers forming a mesh structure (Fig. 2).

The submucosa plate forms numerous papillae of different sizes and heights. The top of the papilla is covered by a transitional epithelium, in which clearly stands out: the basal layer of tightly packed cells containing small rounded darkcolored nuclei, and a surface layer formed from chaotic cells with medium to large nuclei of varying density and color.

12 months after the operative formation of an artificial bladder, the study of the ileum wall revealed no discrepancy with its structure in intact animals.

During macroscopic study, the inner surface of the ileum is velvety, the folds of the mucous membrane are expressed. Wall by the touch is elastic. The outer surface is smooth, shiny.

During microscopic study, the layered organization of the intestine is unaltered. The serous membrane is covered by a single-layer cubic epithelium of the usual form. Below it is a thin plate of soft fibrous fibers, forming a grid, and small thin-walled vessels. Two-layer muscular membrane, layers of medium thickness, separated from each other by a thin connective tissue plate containing a thin-walled vessel and a small amount of intermediate tissue. The bunches of myocytes are distributed tightly, between them are thin interstitial layers, myocytes of the usual type. Submucosal basis is created by a mesh structure from fibrous beams, intermediate substance. In the last distributed lymphoid elements. Closer to the inner surface, certain small lymphatic follicles of the usual structure are determined. In the submucosal layer, Peyer's patches are defined, representing a conglomerate of 3-4 almost square follicles. The structure

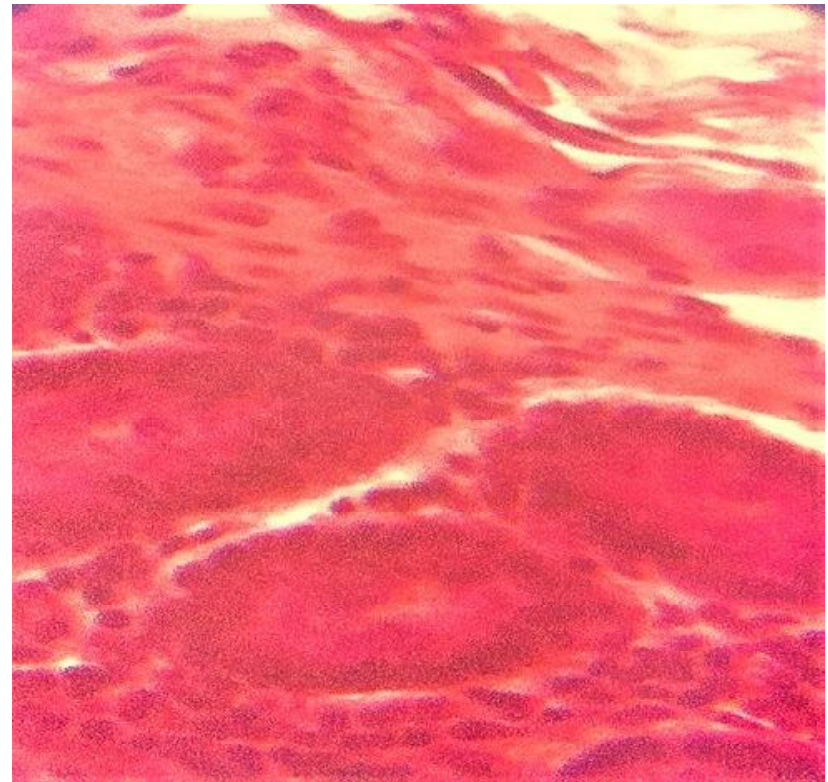

Fig. 1. Ileum of intact mini-pig. Crypts of the mucous membrane. Prismatic epithelium, lymphocytic-histiocytic elements, in the main substance fibrous bundles of the submucosal plate. Hematoxylin-eosin. x160.

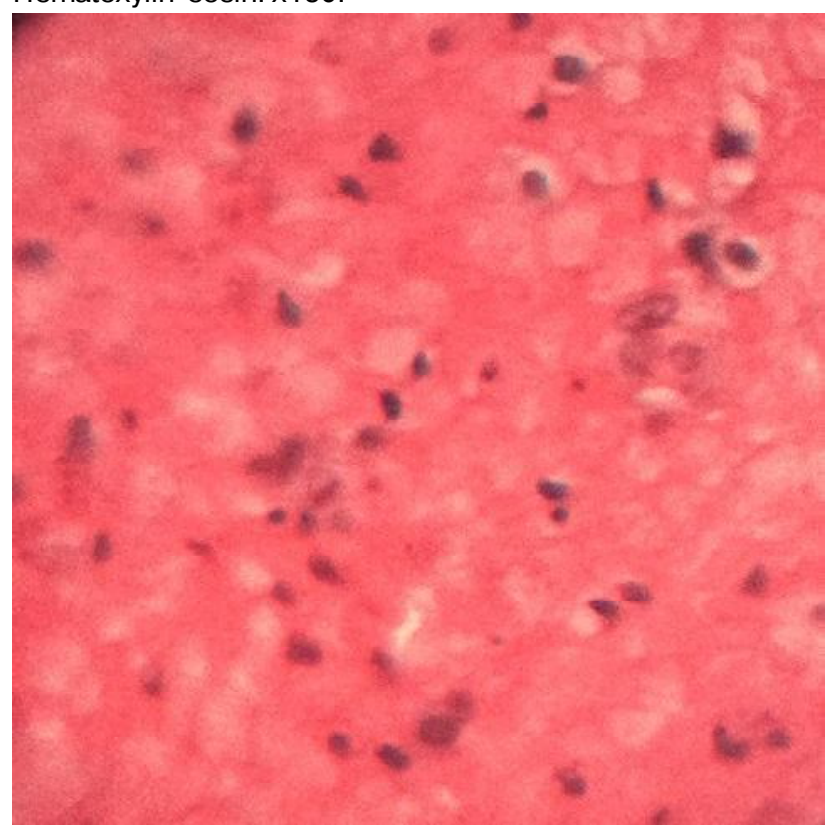

Fig. 2. Bladder of intact mini-pig. Submucosal basis. Histiocytes, fibroblasts. Homogeneous substance. Hematoxylin-eosin. x160.

of each of them without visible features (Fig. 3).

Fibrous plate of the mucous membrane has usual form, thin, in it are located in a moderate amount lymphocytes. Numerous villi of the mucous in shape, size, composition of the central part do not differ from those in control animals.

The top of the villa is covered by the prismatic epithelium with oval nucleuses located as "palisade". Among the epithelial cells there are many glass-shaped cells rich in mucus. 


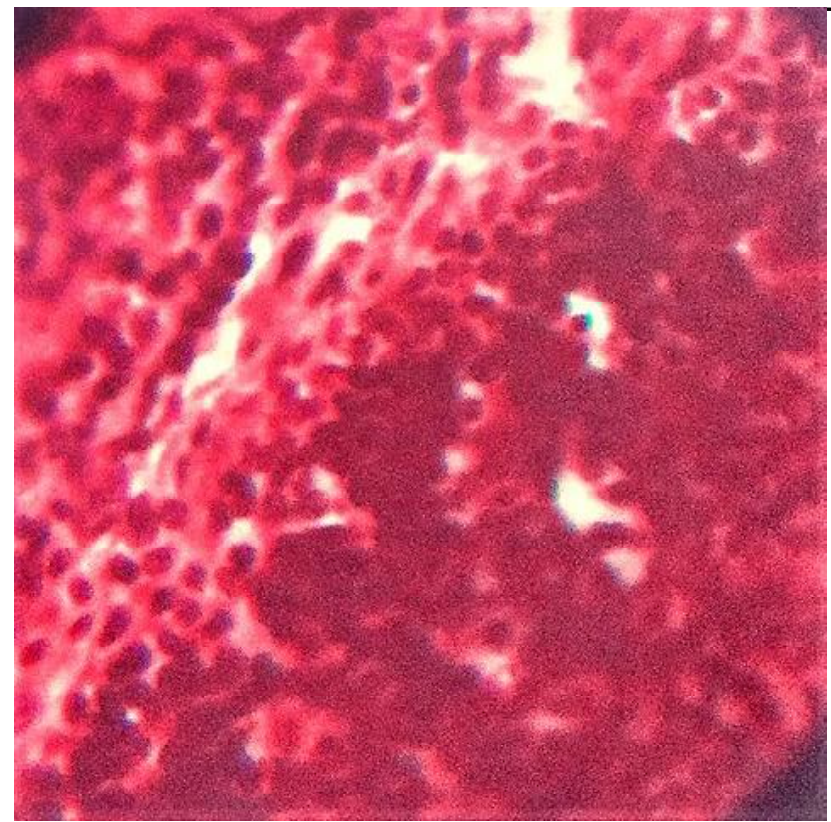

Fig. 3. Ileum of mini-pigs in 12 months after the formation of an artificial bladder. The edge of the Peyer's patch. The usual structure of the peripheral zone of the follicle. Lymphocytes in the perifollicular zone. Hematoxylin-eosin. x160.

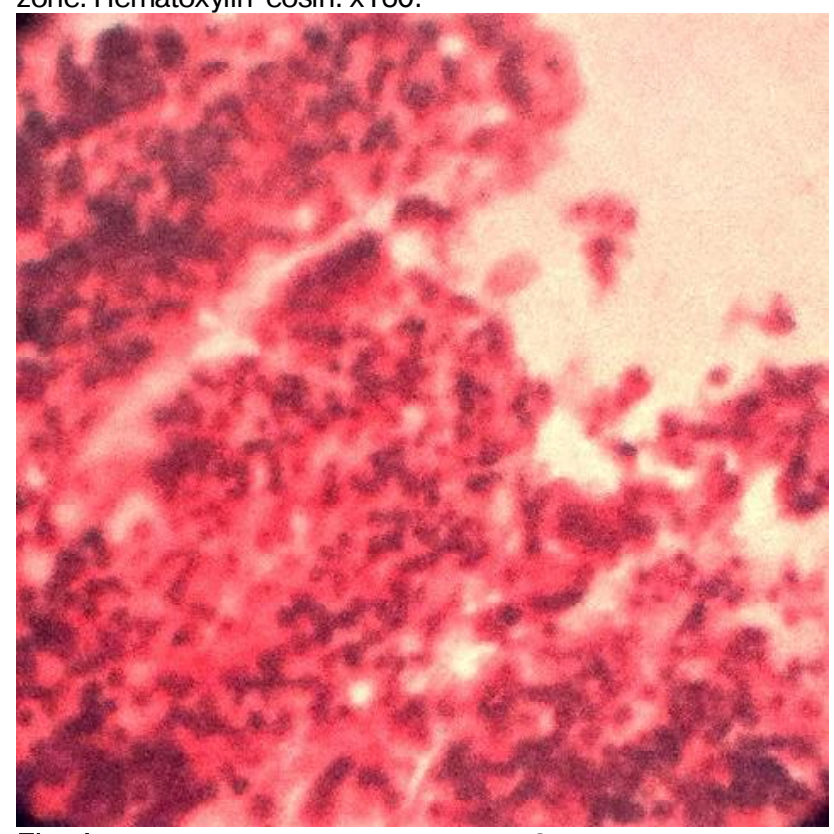

Fig. 4. The wall of the artificial bladder, 12 months after surgery. Epithelium on the surface of the papilla is similar to the intermediate. Hematoxylin-eosin. x160.

The visual assessment of the neobladder did not reveal any particular differences from the native organ. The outer surface is a grayish-pink, shine inner surface with low folds, moist, shiny.

On the touch the wall is quite elastic. Microscopy of the external (serous) membrane revealed that it was formed by a cubic single-layer epithelium of the usual form. Beneath the connective tissue, formed by fibrous fibers, fibroblasts.
Visually, it is wider than the ileum from which the neobladder is formed, with the outer plate of the muscular membrane does not merge.

The muscular membrane is visually wider than the ileum, but also a double layer. Muscle beams are thick enough due to the expansion of myocytes, the cytoplasm in them is homogeneous, the nuclei are enlarged, juicy colored. The interstitial layers between the beams are thin, but fibrous fibers that form them are coarse, many fibroblasts, and then thinwalled moderately full-blood vessels are determined. The bunches of myocytes in each layer are clearly unidirectional. Interlayer plate thicker than in the ileum, thickening is due not only to the coarsening of fibrous fibers, but also with the increase in the amount of intermediate tissue.

Submucosal base broad, as in the ileum, form its bundles of fibrous fibers, forming a mesh structure. Fiber fibers are dyed, juicy, many fibroblasts in bundles. The difference in the basis of the artificial urinary bladder from the corresponding layer in the ileum - in a very large amount of intermediate substance. If in the intestine this substance is dark eosinophilic color, then in neobladder it is brick color obviously changes the chemical composition of this substance. In the intermediate substance, a number of lymphoid elements are scattered. Peyer's patch in the submucosal layer were not detected, nor did lymphoid follicles appear on the border of the mucous membrane. In the mucous membrane stands out a submucosa plate formed by thin beams of fibrous fibers and small inclusions of intermediate substance, fibroblasts with oval juicy nuclei, a few of them. The width of the submucosal plate is unequal, unlike the intestine, due to this formed formations, similar to the papilla or folds. The plate is covered by the epithelium, in its organization similar to the intermediate (Fig. 4).

In the basal layer of the epithelium, the cells are arranged in one row, but in some places, influences from 2-3 rows of cells are formed. Closer to the surface of the cell are sparser, their nuclei are round, medium-sized, moderately colored. It should be noted that "influences" are formed in those places where the submucosa plate is stacked like a papilla or folds, perhaps it is the remnants of degrading villi. The cryptic remains are also determined, they are located between the papillae, laced with the prismatic epithelium, glass-shaped cells in them are small, but there are desquamated epithelial cells.

\section{Discussion}

Our findings of ultrastructural changes in the neobladder mucous membrane with a decrease in microvilli, with the onset of inflammation and the processes of degeneration under the action of urine, are also noted in studies of Kojima Y. with co-authors [13]. The high degree of adaptation processes suggests the constancy of the definition of crypt and glass-shaped cells, as the main placement of Paneth cells, though in small quantities. Paneth cells play a very important role in ileum homeostasis, carrying out bactericidal and regenerative-proliferative action [6]. According to Malone 
M.J. the surface epithelium changes, but without metaplasia and dysplasia [14], but some authors emphasize the high risk of malignant epithelial transformation by the action of urinary agents, since inflammatory cells can produce various growth factors $[16,17]$. Since the lifetime of enterocytes is overly fast (72 hours), this is not a consequence of a genetic mutation. It is more likely that some urine solutions and low internal $\mathrm{pH}$ damage epithelial cells, which then lose microcirculation due to direct toxicity.

Evaluating the observed changes in the wall of the neobladder, we can assume that they have an adaptivecompensatory character, since, being in a new, unusual for themselves functional situation, the tissues of the walls of the ileum acquire the features necessary to perform the new function.

The prospect of further studies of artificial bladder is the study of changes in energy homeostasis, neurohumoral and synoptic regulation, and the search for new drug compounds that can influence the contractile activity of the neobladder

\section{References}

[1] Merkulov, G. A. (1961). Course of pathological histology. L.: Medgiz. Retrievedfromhttps://www.twirpx.com/file/1352585/

[2] Zapadnyuk, V. I., Zakhariya, E. A., \& Zapadnyuk, B. V. (1983). Laboratory animals. Breeding, content, use in the experiment. Kiev: High school. ISBN 5518162189, 9785518162181

[3] Aleksic, P., Bancevic, V., Milovic, N., Kosevic, B., Stamenkovic, D.M., Karanikolas, M. ... Jovanovic, M. (2010). Short ileal segment for orthotopic neobladder: a feasibilitystudy. Int. J. Urol., 17(9):768-773. doi: 10.1111/j.1442-2042.2010.02599.x, 10.1111/j.1442-2042.2010.02600.x, 10.1111/j.14422042.2010.02601.x

[4] Attalla, K., Kent, M., Waingankar, N., Mehrazin, R. (2017). Robotic-assisted radical cystectomy versus open radical cystectomy for management of bladder cancer: review of literature and randomized trials. Future oncology, 13(13). https://doi.org/10.2217/fon-2017-0004.

[5] Baskin, L. S., Hayward, S. W., Di Sandro, M. S., Li, Y. W., \& Cunha, G. R. (1999). Epithelial-mesenchymal interactions in the bladder. Implications for bladder augmentation. Urol. Clin. North Am., 26, 49-59.

[6] Beisner, J., Stange, E., Wehkamp, J. (2010). InnateAntimicrobial Immunity in Inflammatory Bowel Diseases. Expert Rev. Clin. Immunol., 6(5), 809-818. doi: 10.1586/eci.10.56.

[7] Cerruto, M., D'Elia, C., Siracusano, S., Porcaro, A., Cacciamani, G., De Marchi, D. ... Artibani, W. (2017). Is Health-Related Quality of Life after Radical Cystectomy Using Validated Questionnaires Really Better in Patients with lleal Orthotopic Neobladder Compared to lleal Conduit: A Meta-Analysis of Retrospective Comparative Studies. Curr. Urol., 10(2), 5768. doi: 10.1159/000447153.

[8] Chang, D. , \& Lawrentschuk, N. (2015). Orthotopic neobladder reconstruction. Urol. Ann., 7, 1-7. doi:10.4103/09747796.148553.

[9] Dahl, D. M., \& McDougal, W. S. (2007). Use of intestinal segments in urinary diversion; ed. A. J. Wein. 9th ed. CampbellWalsh urology. Philadelphia: Saunders-Elsevier. ISBN: 97814160315501416031553

[10] Hall, M. C., Koch, M. O., Halter, S. A., \& Dahlstedt, S. M. (1993). Morphologic and functional alterations of intestinal and improve the quality of life of patients with orthotopic urinary excretion.

\section{Conclusions}

1. 12 months after ileocystoplasty in the wall of the neobladder formed from the wall of the ileum, observed significant morphological changes, namely: thickening of the muscle membrane, thickening and coarsening of connective tissue in the layers of the neobladder wall, decreasing the number of glass-shaped cells and Paneth cells, from the submucosal basis, Peyer's patch and lymphoid follicles are practically disappearing, the villi are smoothed, the mucosal epithelium becomes similar to that of the intermediate.

2. The tissues of the ileum, remaining in their usual environment, will not undergo any structural transformation. Comparison of the structure of the wall of the native bladder and the neobladder showed that the structure of the latter is close to the first, but because of originally different origin and structure of complete transformation does not occur.

segments following urinary diversion. J. Urol., 149, 664666. https://doi.org/10.1016/S0022-5347(17)36175-X

[11] Hautmann, R. E., de Petriconi, R. C, \& Volkmer, B. G. (2010). Lessons learned from 1,000 neobladders: The 90-day complication rate. J. Urol., 184, 990-994. doi: 10.1016/ j.juro.2010.05.037.

[12] Koga, F., \& Kihara, K. (2012). Selective bladder preservation with curative intent for muscle-invasive bladder cancer: A contemporary review. Int. J. of Urol., 5(19). https://doi.org/ 10.1111/j.1442-2042.2012.02974.x

[13] Kojima, Y., Asaka, H., Ando, Y., Takanashi, R., \& Kohri, K. (1998). Mucosal morphological changes in the ileal neobladder. Br. J. Urol., 82, 114-117.

[14] Malone, M. J., Izes, J. K., \& Hurley, L. J. (1997). Carcinogenesis: the fate of intestinal segments used in urinary reconstruction. Urol. Clin. North. Am., 24, 723-728.

[15] Monteiro, L., \& Kassouf, W. (2017). Radical Cystectomy is the best choice for most patients with muscle-invasive bladder cancer? Opinion:Yes. Int. Braz. J. Urol., 43(2), 184-187. doi: 10.1590/S1677-5538.IBJU.2017.02.03

[16] Naito, A., Kawai, T., Fujimura, T., Morikawa, T., Kume, H., \& Homma, Y. (2014). Adenoma-carcinoma Sequence in the Bladder After Augmentation Cystoplasty. Urol Case Rep, 2(3), 73-74. doi: 10.1016/j.eucr.2014.01.009

[17] Sallami, S. (2009). Mucinous Adenocarcinoma of the lleal Neobladder 20YearsAfter Cystectomy: TheFirstReported Case. Urotoday Int. J., 2(6). doi:10.3834/uij. 1944-5784.2009.12.16

[18] Sun, X., Song, M., Bai, R., Cheng, S., Xing, Y., Yuan, H. ... Zhou, L. (2013). Ileal interposition surgery-induced improvement of hyperglycemia and insulin resistance in GotoKakizaki rats by upregulation of TCF7L2 expression. Exp. Ther. Med., 5, 1511-1515. doi: 10.3892/etm.2013.998

[19] Vajda, P., Kaiser, L., Magyarlaki, T., Farkas, A., Vastyan, A. M., \&Pinter, A. B. (2002). Histological findings after colocystoplasty and gastrocystoplasty. J. Urol., 168(2), 698-701.

[20] Zhang, Y., Song, Q., Song, B., Zhang, D., Zhang, W., Wang, J. (2017). Diagnosis and Treatment of Urinary Incontinence after Orthotopic Ileal Neobladder in China. Chin. Med. J., 130(2), 231-235. doi: 10.4103/0366-6999.198012 
СТРУКТУРНО-ФУНКЦІОНАЛЬНА ТРАНСФОРМАЦІЯ СТІНКИ ТОНКОЇ КИШКИ В УМОВАХ ФУНКЦІОНУВАННЯ ШТУЧНОГО СЕЧОВОГО РЕЗЕРВУАРА В ЕКСПЕРИМЕНТІ

Савчук Р.В., Костєв Ф.І., ЖУковський Д.О., Насібуллін Б.А.

Морфологічні зміни стінки артифіціального сечового міхура різноманітні та ї дослідження триває з моменту створення першого кондуїту із ділянки клубового кишечнику. Метою роботи було вивчення структурно-функціональної трансформації слизової та стінки необладдера через 12 місяців після ілеоцистопластики в експериментальних умовах на карликових домашніх свинях. Матеріалом цієї роботи послужили результати експериментальної моделі необладдера, створеної шляхом виконання цистектомії та ілеоцистопластики у 9 експериментальних карликових домашніх свинях. Через 12 міс. після здійснення операції моделювання сечового міхура тварин виводили з досліду передозуванням нембуталу, дотримуючись положень "Європейської конвенції про захист хребетних тварин, використовуваних для експериментів або в інших наукових цілях". Проведені нами морфологічні дослідження артифіціального сечового міхура, сформованого із сегменту клубової кишки через 12 місяців після ортотопічної ілеопластики, довели значні ультраструктурні зміни в епітеліальному шарі необладдера. Ворсинки клубової кишки в умовах артифіціального сечового міхура зменшувались та згладжувались, епітеліоцити набували подібності із проміжним епітелієм. Сполучнотканинна пластина стовщувалась та грубшала, м'язова оболонка, в свою чергу, також потовщувалась. Зразки клубової кишки, які залишалися в звичайному оточенні, без взаємодії із сечею, не зазнавали значних морфологічних трансформацій та не відрізнялися від зразків інтактної клубової кишки. Таким чином, трансплантація сегменту клубової кишки змушує його адаптуватися до нових умов, хоча від самого початку сечовий міхур та клубова кишка мають різне походження та будову, а нові агресивні умови та постійний контакт із сечею призводять до трансформації слизової клубової кишки та набування нових якостей, необхідних для виконання нових, не запрограмованих функцій.

Ключові слова: радикальна цистектомія, ілеоцистопластика, трансформація слизової, необладдер.

СТРУКТУРНО-ФУНКЦИОНАЛЬНАЯ ТРАНСФОРМАЦИЯ СТЕНКИ ТОНКОЙ КИШКИ В УСЛОВИЯХ ФУНКЦИОНИРОВАНИЯ ИСКУССТВЕННОГО МОЧЕВОГО РЕЗЕРВУАРА В ЭКСПЕРИМЕНТЕ Савчук Р.В., Костев Ф.И., Жуковский Д.А., Насибуллин Б.А.

Морфологические изменения стенки артифициального мочевого пузыря разнообразные и их исследование продолжается с момента создания первого кондуита из участка подвздошной кишки. Целью работы было изучение структурнофункциональной трансформации слизистой необладдера через 12 месяцев после илеоцистопластики в экспериментальных условиях на карликовых домашних свиньях. Материалом этой работы послужили результаты экспериментальной модели необладдера, созданной путем выполнения цистэктомии и илеоцистопластики у 9 экспериментальных карликовых домашних свиней. Через 12 мес. после проведения операции моделирования мочевого пузыря животных выводили из опыта передозировкой нембутала, придерживаясь положений "Европейской конвенции о защите позвоночных животных, используемых для экспериментов или в иных научных целях". Наши морфологические исследования артифициального мочевого пузыря, сформированного из сегмента подвздошной кишки через 12 месяцев после ортотопической илеопластики, доказали значительные ультраструктурные изменения в эпителиальном слое необладдера. Ворсинки подвздошной кишки в условиях артифициального мочевого пузыря уменьшались и сглаживались, эпителиоциты приобретали сходство $c$ промежуточным эпителием. Соединительно-тканная пластина утолщалась и огрубевала, мышечная оболочка, в свою очередь, также утолщалась. Образцы подвздошной кишки, которые оставались в обычном окружении, без взаимодействия с мочой, не испытывали значительных морфологических трансформаций и не отличались от образцов интактной подвздошной кишки. Таким образом, трансплантация сегмента подвздошной кишки заставляет его адаптироваться к новым условиям, хотя изначально мочевой пузырь и подвздошная кишка имеют различное происхождение и строение, а новые агрессивные условия и постоянный контакт с мочой приводят к трансформации слизистой подвздошной кишки и приобретению новых качеств, необходимых для выполнения новых, не запрограммированных функций.

Ключевые слова: радикальная цистэктомия, илеоцистопластика, трансформация слизистой, необладдер. 